\title{
PENINGKATAN KETERAMPILAN MEMBACA PUISI DENGAN EKSPERIMENTASI MODEL CIRC BERMEDIA VIDEO PEMBACAAN PUISI PADA SISWA KELAS V SD 1 TRITIS JEPARA
}

\author{
Sajida Laila Hanif ${ }^{1}$, Irfai Fathurohman ${ }^{2}$, Sumarwiyah ${ }^{3}$ \\ Email: 201433128@std.umk.ac.id, irfai.fathurohman@umk.ac.id, \\ sumarwiyah@umk.ac.id \\ Prodi Pendidikan Guru Sekolah Dasar, \\ Prodi Pendidikan Bahasa dan Sastra Indonesia, \\ Prodi Bimbingan dan Konseling, \\ Fakultas Keguruan dan Ilmu Pendidikan, \\ Universitas Muria Kudus, Indonesia
}

\begin{abstract}
Abstrak
Penelitian ini merupakan penelitian tindakan kelas. Permasalahan mendasar penelitian ini adalah kurangnya keterampilan siswa dalam membaca puisi serta masih sulitnya mempraktikkan cara membaca puisi dengan membaca karya sastra lainnya. Tujuan dari penelitian ini menjelaskan aplikasi dari model CIRC berbantuan media video pembacaan puisi serta menemukan peningkatan keterampilan membaca puisi pada siswa kelas V SD 1 Tritis Jepara dengan model dan media tersebut. Sebanyak 28 siswa dan guru sebagai subjek penelitian ini. Hasil penelitian menunjukkan bahwa terjadi peningkatan dari siklus I sebesar $64 \%$ menjadi $89 \%$ pada siklus II. Hal ini merupakan bukti peningkatan keterampilan membaca puisi siswa kelas V SD 1 Tritis Jepara dengan eksperimentasi model CIRC berbantuan media video pembacaan puisi.
\end{abstract}

Kata Kunci: Keterampilan Membaca, Model CIRC, dan Media Video Pembacaan Puisi.

\begin{abstract}
This is classroom action research. The fundamental problem of this research is the lack of student skill in reading poem and difficulty in practicing to read the poem by another literary works. The objective of this research to explain application of CIRC model equipped by poem reading video media and to find out the improvement of poem reading skill student grade VSD 1 Tritis Jepara with it. Total 28 students and a teacher as a research subject. The finding shows there happened an improvement poem reading skill from cylce 1 in range $64 \%$ to $89 \%$ in second two. This evidence of poem reading skill student grade V SD 1 Tritis Jepara with CIRC model experimentation equipped by poem reading video media.
\end{abstract}

Keywords: Reading Skill, CIRC Model, and Poem Reading Video Media.

\section{PENDAHULUAN}

Indonesia merupakan negara yang terdiri dari bermacam suku, ras, agama, serta bahasa. Setiap daerah memiliki bahasa yang berbeda-beda, maka bahasa Indonesia hadir sebagai bahasa persatuan. Pembelajaran Bahasa Indonesia wajib diajarkan pada sekolah-sekolah di Indonesia, karena dengan pembelajaran Bahasa Indonesia cara untuk berkomunikasi secara lisan dan tertulis dengan bahasa yang baik dan benar diajarkan. Salah satu aspek keterampilan dasar kebahasaan adalah membaca, namun penelitian ini lebih memfokuskan pada keterampilan membaca puisi.

Permasalahan berkaitan dengan keterampilan membaca puisi yang ditemukan di SD 1 Tritis Jepara antara lain siswa masih merasa takut untuk berpartisipasi dalam kegiatan pembelajaran, siswa hanya menjadi penonton saat guru mencontohkan cara membaca puisi, kemudian setelah siswa diminta guru untuk membaca puisi mereka tidak bisa karena ada yang sibuk bermain sendiri dan malu jikalau salah, serta cara mengajar guru masih menggunakan metode konvensional yakni ceramah. 
Berdasarkan hasil observasi di SD 1 Tritis Jepara pada tanggal 8 September 2017, diperoleh data nilai hasil ulangan siswa pelajaran Bahasa Indonesia materi membaca puisi, KD membaca puisi anak dengan lafal dan intonasi yang tepat masih kurang maksimal. Hal ini dibuktikan dari 28 siswa, hanya 12 siswa yang tuntas atau 16 siswa tidak tuntas. Rincian nilainya sebagai berikut; nilai 0 diperoleh 2 siswa, nilai 50 diperoleh 2 siswa, nilai 60 diperoleh 1 siswa, nilai 70 diperoleh 7 siswa, nilai 77 diperoleh 4 siswa, sedangkan hanya 5 siswa yang memperoleh nilai 80 , dengan penetapan kriteria ketuntasan minimal oleh SD 1 Tritis Jepara sebesar 75 .

Seiring dengan perkembangan zaman yang semakin maju, hendaknya guru tidak selalu mengandalkan metode masa lalu dalam pembelajaran namun juga tidak benar-benar meninggalkannya. Inovasi dalam pembelajaran tentu sangat dibutuhkan untuk mengatasi berbagai macam kelemahan dan kekurangan yang ditemukan, salah satunya menggunakan model pembelajaran. Guru masih harus jeli dan teliti memilah dan memilih model yang cocok untuk diterapkan. Berkaitan dengan pembelajaran membaca, model pembelajaran yang sesuai adalah CIRC (Cooperative Integrated Reading and Composition).

Shoimin (2014: 52) berpendapat dari segi bahasa model kooperatif CIRC adalah model pembelajaran yang mengedepankan kerjasama antar siswa dalam membaurkan suatu bacaan secara holistik menjadi bagian-bagian terpenting saja.

Masing-masing siswa memiliki ciri khas yang berbeda-beda antara satu dengan yang lainnya, termasuk dalam cara membaca puisi. Maka dari itu, tujuan dari CIRC mempermudah siswa dalam mengembangkan kemampuan tersebut. Disadari atau tidak, dengan ditampilkannya contoh cara membaca puisi dapat memberikan pandangan pada siswa untuk membaca puisi dengan baik sesuai lafal, intonasi, gaya dan ekspresinya. Jadi, kehadiran media pembelajaran juga dibutuhkan untuk menunjang model pembelajaran yang digunakan, dalam hal ini model CIRC. Contoh dari media pembelajaran yang berhubungan dengan membaca puisi yang tak tertinggal dari teknologi yaitu media video pembacaan puisi.

Penggunaan video pembacaan puisi dinilai lebih tepat waktu dan tepat guna karena pembacaan puisi dapat diputarkan berkali-kali serta dapat memilih contoh puisi terbaik tanpa harus menghadirkan pembaca puisi secara langsung di depan kelas. Tetapi, media video pembacaan puisi peneliti menggabungkan keduanya, karena di dalam video tersebut peneliti sendiri yang membacakan puisi karyanya, yakni puisi Balada, Himne, Elegi, dan Ode. Tak hanya itu, sebagai penguat agar siswa mampu membaca puisi dengan baik, peneliti juga memberikan contoh membaca puisi secara langsung di depan kelas, serta memberikan kesempatan siswa untuk berlatih bersama anggota kelompoknya.

Tujuan penelitian ini adalah untuk memaparkan keterampilan guru dalam pembelajaran membaca puisi dengan model CIRC dibantu media video pembacaan puisi, menjelaskan aktivitas siswa dalam pembelajaran membaca puisi dengan model CIRC dibantu media video pembacaan puisi, serta menemukan peningkatan keterampilan membaca 
puisi siswa dengan model CIRC dibantu media video pembacaan puisi.

Berdasarkan tujuan tersebut, peneliti mencetuskan judul "Peningkatan Keterampilan Membaca Puisi dengan Eksperimentasi Model CIRC Bermedia Video Pembacaan Puisi pada Siswa Kelas V SD 1 Tritis Jepara."

\section{KAJIAN PUSTAKA}

\section{a. Definisi Membaca}

$$
\text { Harimurti Kridalaksana }
$$
(2009:151) mengutarakan membaca adalah menggali informasi dari suatu teks, baik berupa tulisan, diagram atau gambar, maupun dari kombinasi semuanya. Membaca juga merupakan keterampilan mengenal dan memahami tulisan dalam bentuk urutan lambang-lambang grafis dan perubahannya menjadi wicara bermakna dalam bentuk pemahaman diam-diam atau pengujaran keras keras. Klein (1991: 22) menjelaskan cakupan membaca terdiri atas (1) membaca sebagai suatu yang proses, (2) membaca sebagai strategis, dan (3) membaca sebagai suatu interaktif. Membaca sebagai suatu proses diartikan informasi teks serta pengetahuan pembaca mempunyai dominasi atau peran utama terbentuknya suatu makna. Membaca sebagai suatu strategis berarti penggunaan beragam strategi membaca sesuai teks dan konteksnya dapat mempengaruhi keefektifan membaca ketika otak bekerja mengkonstruksi makna tersebut saat membaca. Strategi disesuaikan dengan jenis teks dan tujuan membaca. Sedangkan membaca sebagai interaktif yang dimaksud adalah keterlibatan pembaca dengan teks tergantung pada konteks. Orang yang gemar membaca teks yang mengandung manfaat, akan menemukan beberapa tujuan yang hendak dicapainya, tentu teks yang dibaca juga harus mudah dipahami sehingga dapat terjadi interaksi antara pembaca dengan teks. Dalman (2014: 5) mengutarakan proses berpikir seseorang yang berusaha memahami berbagai informasi yang tertera dalam tulisan. Maka dari itu membaca bukan hanya sekadar melihat huruf yang membentuk kata, kalimat, maupun paragraf akan tetapi cenderung lebih mendalam dalam menggali informasi yang disampaikan penulis sehingga pesan tersebut dapat diterima oleh pembaca. Berdasarkan kumpulan dari berbagai pendapat ahli tersebut, simpulan dari membaca adalah suatu keterampilan dalam rangka memahami pola-pola bahasa dari suatu lambang tulis maupun ucapan lisan agar pesan yang disampaikan dapat diterima dan dipahami secara baik dan sempurna.

Crawlet dan Mountain (dalam Rahim, 2008: 2) menyebut pada hakikatnya membaca adalah kegiatan yang kompleks dan melibatkan banyak hal, tidak hanya melafalkan tulisan, tapi melibatkan pula aktivitas visual, berpikir, psikolinguistik, dan metakognitif. Disebut proses visual, karena membaca merupakan aktivitas menerjemahkan huruf ke dalam kata-kata lisan. Membaca sebagai proses kognitif, karena dalam membaca terlibat juga aktivitas pengenalan kata, interpretasi, serta pemahaman kreatif. Achmad (dalam Kariesma, 2014: 2) mengidentifikasi empat proses dalam membaca yakni persepsi, komprehensi, reaksi, dan integrasi. Jadi simpulannya adalah hakikat membaca merupakan proses 
memahami makna dalam bacaan yang diperoleh dari interaksi timbal balik antara pembaca yang disajikan dengan kalimat fakta serta informasi di dalam kalimat bacaan.

Pembaca yang baik pasti mempunyai tujuan dari bahan bacaan yang dibacanya. Tujuan utama dalam membaca adalah untuk mencari dan menemukan informasi, mencakup isi, dan memahami makna bacaan tersebut. Seperti halnya Tarigan (2008: 9-10) yang memaparkan tujuan membaca anatara lain (1) membaca untuk mengetahui hal yang tokoh lakukan untuk memperoleh fakta, (2) membaca untuk mengetahui topik yang baik dan menarik untuk memperoleh gagasan utama, (3) membaca untuk mengetahui setiap bagian cerita untuk menemukan susunan cerita, (4) membaca untuk mengetahui mengapa tokoh melakukan suatu hal untuk menyimpulkan, (5) membaca untuk mengetahui sesuatu yang tidak biasa dari suatu tokoh untuk mengklasifikasikan, (6) membaca untuk menemukan apakah tokoh berhasil hidup dengan ukuran tertentu untuk mengevaluasi, dan (7) membaca untuk mempertentangkan sesuatu. Senada dengan Salad (2014: 34) yang menyatakan bahwa tujuan pokok membaca adalah mengetahui dengan jelas pesan yang tersimpan dalam bacaan, baik diutarakan secara gamblang maupun tersembunyi. Jadi, dapat disimpulkan bahwa tujuan membaca adalah menggali informasi yang terkandung dalam suatu bacaan dengan memahaminya secara sungguh-sungguh sehingga dapat diperoleh fakta dan menjadikan semakin kayanya pengetahuan pembaca.

\section{b. Puisi}

Karya

sastra yang mementingkan aspek kebahasaan dengan kata-kata indah dan imajinatif dalam bentuk lebih padat dengan pemilihan diksi yang tepat dinamakan puisi (Nurgiyantoro, 2005: 312). Salad (2014: 124) mengutarakan hakikat puisi adalah kumpulan kata yang elok yang tersusun di atas kertas, lembaran buku atau media lain yang sejenis. Puisi merupakan karya sastra, akan tetapi sebagian orang masih memandang karya sastra sebagai sesuatu yang tak ada gunanya, faktanya tidak seperti itu. Puisi mempunyai fungsi dapat memperkuat organ moral manusia, sama seperti halnya pendidikan jasmani serta dengan puisi kita seakan-akan dapat melihat hal yang tidak pernah kita lihat dan mendengar apa yang tidak pernah kita dengar (Shelley dalam Sopandi, 2010: 5). Jadi, puisi merupakan suatu karya sastra penuh unsur keindahan, kata padu dan imajinatif agar pembaca dapat merasakan suasana dan memahami makna dalam puisi tersebut.

Damayanti (2013: 73-76) membagi puisi menjadi tiga jenis yakni (1) puisi lama adalah puisi yang terikat aturan seperti pantun, mantra, gurindam, peribahasa, dll, (2) puisi baru adalah puisi yang terbebas dari aturan seperti balada, romansa, elegi, dst, (3) puisi kontemporer adalah puisi yang menyesuaikan dengan keadaan zaman seperti puisi mantra, puisi mbeling, dan puisi konkret. Suroto (dalam Yuliandri, 2016: 37) menjelaskan pembagian puisi modern yakni (1) badala yaitu puisi yang berisi suatu kisah, (2) romansa yaitu puisi yang menggambarkan 
kasih sayang terhadap seseorang, (3) himne yaitu puisi pujian-pujian terhadap Tuhan atau sesuatu yang dianggap mulia, (4) elegi yaitu puisi yang melambangkan kesedihan, (5) Ode yaitu puisi yang bertema mulia, dan (6) satire merupakan puisi berisikan sindiran terhadap orang maupun keadaan.

Waluyo (2010: 2) memaparkan ciri kebahasaan puisi antara lain (1) pemadatan bahasa, dimana bahasa puisi bukan seperti alenia akan tetapi larik, (2) pemilihan kata khas seperti makna kias, perlambangan, dan rima yang benar-benar diperhatikan penyair agar puisi semakin indah dan bermakna dalam, (3) kata konkret menggambarkan sesuatu yang lebih konkret bagi penyair, namun sering kali pembaca sulit mengartikannya, (4) pengimajian adalah kata atau susunan kata yang dapat memperjelas maksud penyair, diantaranya imaji visual, auditif, dan taktil, (5) Irama berhubungan dengan kata, frasa, kalimat, dan bunyi, serta (6) tata wajah puisi ibarat menggambarkan isi dalam puisi yang dibaca.

L.A. Richards (dalam Waluyo, 2010: 124-151) membagi unsur puisi menjadi empat bagian, yakni (1) tema merupakan gagasan pokok yang diungkapkan penyair, (2) perasaan dalam menciptakan puisi harus diekspresikan penyair agar pembaca dapat merasakan suasananya, (3) nada dan suasana. Nada adalah sikap penyair terhadap pembaca, sedangkan suasana adalah akibat yang ditimbulkan puisi setelah pembaca membacanya, dan (4) amanat merupakan pesan yang hendak disampaikan penyair.

Langkah-langkah

dalam membaca puisi yakni (1) pahami isi puisi sebelum membacanya, (2) berilah jeda teks berdasarkan kesatuan makna agar mudah dalam membaca, (3) berilah tekanan yang tepat, (4) bacalah puisi dengan penuh penghayatan, bersungguh-sungguh, dan total, (5) sering berlatih membaca puisi agar dapat menemukan irama yang tepat.

\section{c. Model CIRC}

Slavin (dalam Kariesma, 2014: 3) mengutarakan bahwa CIRC merupakan salah satu tipe model pembelajaran kooperatif yang cocok digunakan dalam pembelajaran membaca dan menulis. Sejalan dengan pendapat tersebut, Rahim (2011: 35) pun menyatakan bahwa pendekatan pembelajaran kooperatif yang lebih cocok bagi pembelajaran membaca adalah metode CIRC. Jadi, model CIRC adalah model pembelajaran kooperatif yang menyusun bagian-bagian penting dalam suatu bacaan untuk mengembangkan kemampuan membaca dan menulis.

Shoimin (2014: 52) bahwa sintaks penerapan model CIRC adalah sebagai berikut.

1) Membentuk kelompok Guru membentuk siswa menjadi beberapa kelompok heterogen.

2) Memberikan wacana

Guru menyampaikan tujuan pembelajaran, materi yang hendak dipelajari, serta apa yang harus dilakukan siswa selama kegiatan pembelajaran.

3) Kerjasama

Siswa bekerja sama dengan rekan satu timnya untuk berlatih membaca puisi.

4) Presentasi

Masing-masing anggota tim membacakan puisi di depan kelas. 
5) Kesimpulan

Siswa bersama guru menyimpulkan materi yang telah dipelajari.

6) Penguatan

Siswa bersama guru merefleksikan, mengevaluasi serta memberikan penguatan terhadap pembelajaran yang telah dilakukan.

Shoimin (2014: 54) turut menjelaskan kelebihan model CIRC antara lain dapat membuat siswa aktif dan dominasi guru lebih berkurang, cocok bagi pembelajaran membaca dan menulis, siswa lebih teliti dan bersemangat karena bekerja dalam kelompok, serta membantu meningkatkan hasil belajar. Selain kelebihan, model CIRC juga terdapat kelemahan yaitu tidak dapat dipakai untuk pembelajaran dengan prinsip menghitung seperti matematika, fisika, dan kimia.

\section{d. Media Video Pembacaan Puisi}

Segala sesuatu yang dapat digunakan untuk menyampaikan pesan dari pengirim kepada penerima disebut media (Sadiman, 2014: 7). Salah satu jenis media adalah video. Sadiman (2014: 74) menyebutkan video sebagai media audio-visual yang menampilkan gerak dan diminati oleh masyarakat. Media video pembacaan puisi berarti video yang berisi pembacaan puisi, dalam penelitian ini guru bertindak sebagai pembaca puisi dalam video tersebut.

\section{METODE PENELITIAN}

\section{a. Jenis Penelitian}

Jenis penelitian yang digunakan peneliti ialah penelitian tindakan kelas, yang terdiri atas dua siklus, yakni siklus I (dua kali pertemuan) dan siklus II (dua kali pertemuan). b. Tempat dan Waktu Penelitian Pelaksanaan penelitian bertempat di SD 1 Tritis Jepara tahun pelajaran 2017/2018. Penelitian tindakan kelas ini dilakukan pada bulan September 2017 sampai dengan bulan Desember 2017, mulai dari tahap persiapan, pelaksanaan, hingga pelaporan.

\section{c. Karakteristik Penelitian}

Subjek

Peneliti sebagai guru dan siswa kelas V SD 1 Tritis Jepara yang berjumlah 28 siswa (terdiri atas 16 siswa laki-laki dan 12 siswa perempuan) merupakan subjek dalam penelitian ini. Fokus penelitiannya yaitu meningkatkan keterampilan membaca puisi menggunakan model CIRC berbantuan media video pembacaan puisi pada mata pelajaran Bahasa Indonesia. Rancangan penelitian memakai desain model dari Kemmis dan Mc. Taggart (dalam Arikunto, 2012: 16).

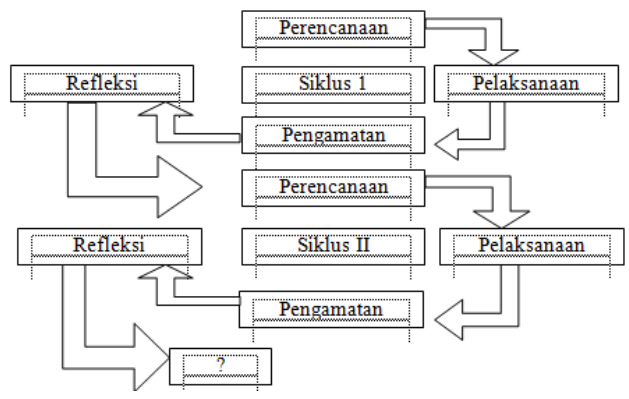

Gambar 1.1 Desain PTK Model Kemmis dan Mc. Taggart

Sumber: Arikunto (2012: 16)

\section{HASIL DAN PEMBAHASAN}

Penelitian ini membahas mengenai beberapa aspek yaitu keterampilan guru dalam mengajar, aktivitas siswa dalam pembelajaran, serta peningkatan keterampilan membaca puisi siswa. 
a. Hasil

Sebelum melaksanakan siklus I, peneliti melakukan prapenelitian tindakan kelas. Nilai UTS pada mata pelajaran Bahasa Indonesia menunjukkan 12 siswa belum mencapai KKM dengan tingkat ketuntasan hanya sebesar 57\%. Hal ini terjadi karena masih banyaknya kekurangan dalam pembelajaran yang guru berikan dan harus dibenahi pada siklus selanjutnya.

\section{Siklus I}

Siklus I dilaksanakan dalam 2 pertemuan dengan alokasi waktu $2 \times 35$ menit, pada tanggal 5 dan 7 Desember 2017 dengan materi puisi Balada dan Himne. Peneliti bertindak sebagai guru dalam penelitian ini.

\section{1) Keterampilan Guru Mengelola Pembelajaran Siklus I \\ Pada dasarnya, guru telah} memiliki keterampilan mengajar cukup baik namun baik dari guru maupun siswa masih sama-sama menyesuaikan diri dalam pembelajaran. Guru berusaha memperbaiki cara mengajar dari yang semula siswa diberitahu menjadi siswa mencoba mencari tahu sendiri. Awal kegiatan, guru menjelaskan tahapan pembelajaran menggunakan model CIRC berbantuan media video pembacaan puisi dan menginformasikan kepada siswa apa yang harus dilakukan pada saat pembelajaran.

Stimulasi juga guru berikan untuk memotivasi siswa menuju materi yang akan dipelajari.

Fenomena pembelajaran sudah mulai terlihat ketika masih terdapat beberapa siswa dengan asyik berbicara dengan teman sebangkunya maupun melemparkan candaan kepada temannya yang lain, ini mengakibatkan konsentrasi siswa dalam kelas menjadi terpecah, guru mulai memberi peringatan secara verbal agar siswa tertib dalam mengikuti pembelajaran.

Keheterogenan kompetensi masing-masing siswa menjadikan suasana pembelajaran menjadi lebih hidup karena disatukan dalam kelompok. Tetapi pada kenyataannya, siswa dengan kompetensi rendah sungkan untuk meminta bantuan pada siswa lain yang lebih mampu dan sebaliknya.

Hal ini tentu menjadikan pembelajaran kurang optimal karena banyak waktu guru yang terbuang hanya untuk mengingatkan mereka. Guru tetap berusaha menjadi penengah dan fasilitator agar mereka saling bekerjasama antar anggota dalam kelompok.

Adapun tabel peningkatan keterampilan guru dalam mengelola pembelajaran Siklus I tersaji sebagai berikut.

Tabel 1.1 Keterampilan Guru dalam Mengajar Siklus I

\begin{tabular}{|c|c|c|c|c|}
\hline Siklus I & Skor & $\begin{array}{c}\text { Skor } \\
\text { Maksimal }\end{array}$ & Persentase & $\begin{array}{c}\text { Rata-Rata } \\
\text { Skor }\end{array}$ \\
\hline Pertemuan 1 & 82 & 100 & $82 \%$ & 84 \\
\hline Pertemuan 2 & 86 & 100 & $86 \%$ & 8 \\
\hline
\end{tabular}

Data di atas tersaji dalam gambar berikut. 
Gambar 1.2 Keterampilan Guru dalam Mengajar Siklus I

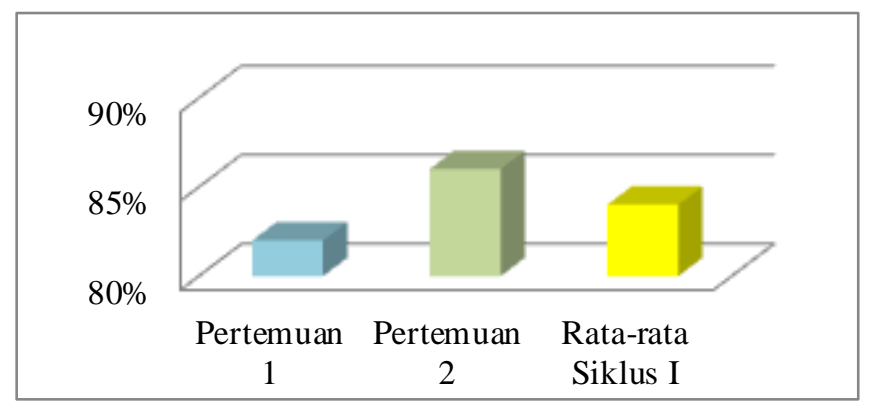

\section{2) Aktivitas Belajar Siswa Siklus I}

Aktivitas belajar siswa siklus I dapat dikatakan cukup baik mengingat masih terdapat kekurangan di sana-sini antara lain siswa cenderung masih pasif pada saat proses kegiatan belajar mengajar berlangsung, walaupun guru sudah menjelaskan di awal mengenai apa yang harus dilakukan siswa pada saat pembelajaran, nyatanya sebagian siswa masih merasa kebingungan sehingga guru perlu membimbing untuk melaksanakan tugas tersebut, hal itu dipicu karena sikap mereka saat pembelajaran kurang fokus.

Proses pembelajaran siklus I pertemuan pertama terdapat siswa yang berbicara sendiri dengan temannya yaitu AAR, MAR, dan MRS.
AAR dan JAF hanya duduk terdiam dan tidak menjawab pertanyaan yang guru ajukan, sedangkan RK, RPP, ZAF sering asyik sendiri membicarakan materi di luar materi yang guru sampaikan.

Siklus I pertemuan II telah mengalami perubahan yakni sebagian besar siswa memiliki kesadaran untuk memperhatikan materi yang disampaikan guru, selain itu kerjasama dalam kelompok semakin meningkat. Namun masih sama seperti pertemuan I, AAR, HAY, ZAF masih membuat kegaduhan di dalam kelas sehingga guru harus sabar mengingatkan serta memberi motivasi pada mereka agar disiplin mengikuti kegiatan pembelajaran.

Tabel 1.2 Aktivitas Siswa Siklus I

\begin{tabular}{|c|c|c|c|}
\hline Siklus I & Total Skor & Persentase & Rata-rata Skor \\
\hline Pertemuan 1 & 700 & $71 \%$ & \multirow{2}{*}{$74 \%$} \\
\hline Pertemuan 2 & 750 & $77 \%$ & \\
\hline
\end{tabular}

Hasil pengamatan aktivitas belajar siswa siklus I tersebut dibuat gambar 1.3 sebagai berikut. 
Gambar 1.3 Aktivitas Belajar Siswa Siklus I

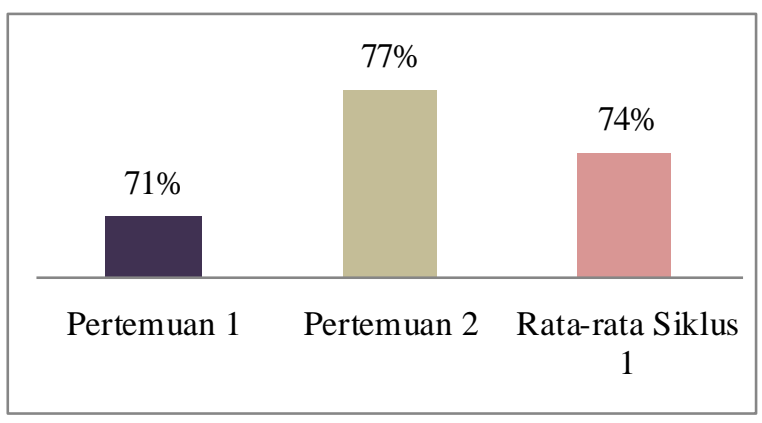

\section{3) Keterampilan Membaca Puisi Siklus I}

Penilaian hasil belajar membaca puisi siswa pada siklus I menunjukkan adanya peningkatan nilai siswa dari prasiklus yakni sejumlah 18 siswa mencapai nilai KKM dengan persentase $67 \%$. Pembelajaran keterampilan membaca puisi siklus I sudah tergolong baik, namun beberapa siswa masih belum lancar dan malu untuk membacakan puisi.
Penilaian membaca puisi yang mencakup gaya, ekspresi, intonasi, dan lafal masih kurang maksimal ketika siswa tampil membaca puisi di depan kelas. Berdasarkan hasil tersebut, guru melakukan evaluasi dan perbaikan terhadap masalahmasalah yang dijumpai pada siklus I. Guru mengajak siswa untuk berlatih membaca puisi bersama sebelum siswa membacakan puisi di depan kelas sebagai penilaian keterampilan membaca puisi. Perhatikan tabel 1.3 di bawah ini!

Tabel 1.3 Peningkatan Keterampilan Membaca Puisi Siswa

\begin{tabular}{|c|c|c|c|c|c|}
\hline \multirow{2}{*}{ Nilai } & \multirow{2}{*}{ Keterangan } & \multicolumn{2}{|c|}{ Prasiklus } & \multicolumn{2}{c|}{ Siklus I } \\
\cline { 3 - 6 } & & $\begin{array}{c}\text { Jumlah } \\
\text { Siswa }\end{array}$ & Persentase & $\begin{array}{c}\text { Jumlah } \\
\text { Siswa }\end{array}$ & Persentase \\
\hline$\geq 75$ & Tuntas & 16 & $57 \%$ & 18 & $64 \%$ \\
\hline$\leq 75$ & Tidak Tuntas & 12 & $43 \%$ & 10 & $36 \%$ \\
\hline \multicolumn{2}{|c|}{ Jumlah } & 28 & $100 \%$ & 28 & $100 \%$ \\
\hline
\end{tabular}

Berdasarkan tabel 1.3 tersebut, maka dapat disajikan gambar berikut ini.

Gambar 1.4 Peningkatan Keterampilan Membaca Puisi Siswa Prasiklus ke Siklus I

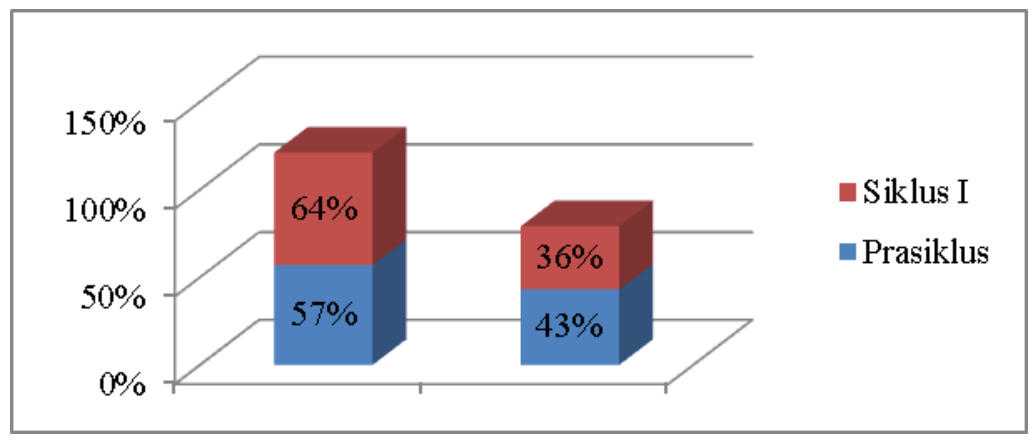




\section{Refleksi Pembelajaran Siklus I}

Tujuan dari refleksi adalah untuk menemukan kendala yang dihadapi selama pembelajaran pada siklus I untuk diperbaiki pada siklus II. Perencanaan perbaikan pada siklus II agar hasil belajar semakin meningkat pada siklus II antara lain.

1. Guru memberikan motivasi dan pertanyaan menuju materi.

2. Guru memperjelas penjelasan langkah model CIRC dan kegiatan yang harus dilakukan siswa.

3. Guru membimbing siswa yang mempunyai kesulitan dalam praktik membaca puisi.

4. Guru memberikan penghargaan bagi siswa yang aktif dalam pembelajaran.

\section{Siklus II}

Pembelajaran siklus II dilakukan dalam 2 pertemuan dengan alokasi waktu $2 \times 35$ menit, pada tanggal 14 dan 16 Desember 2017 dengan materi puisi Elegi dan Ode.

\section{1) Keterampilan Guru Mengelola Pembelajaran Siklus II}

Belajar dari kekurangan pada siklus I, siklus II guru sudah mampu memaksimalkan pembelajaran yang dilakukan. Materi pembelajaran serta model CIRC yang hendak diajarkan pada siswa telah guru perdalam dan kuasai, tidak heran jika keterampilan mengajar guru siklus II semakin baik dan meningkat dengan kelebihan (1) guru mampu memberikan arahan pada siswa untuk melaksanakan sintaks model CIRC berbantuan media video pembacaan puisi, (2) pengelolaan kelas mampu dikendalikan guru dengan baik sehingga keadaan kelas semakin kondusif, (3) guru memberikan latihan kepada siswa untuk membaca puisi secara serentak sebelum penilaian sehingga siswa lebih percaya diri, (4) pemberian semangat oleh guru kepada siswa juga berhasil sehingga siswa semakin aktif dalam pembelajaran. Hal ini semua menyebabkan pembelajaran menjadi lebih efektif, efisien, bermakna dan tentunya menyenangkan. Berikut merupakan tabel peningkatan keterampilan mengajar guru siklus II.

Tabel 1.4 Keterampilan Guru dalam Mengajar Siklus II

\begin{tabular}{|c|c|c|c|c|}
\hline Siklus II & Skor & $\begin{array}{c}\text { Skor } \\
\text { Maksimal }\end{array}$ & Persentase & $\begin{array}{c}\text { Rata-rata } \\
\text { Skor }\end{array}$ \\
\cline { 1 - 3 } Pertemuan 1 & 90 & 100 & $90 \%$ & \multirow{2}{*}{$92 \%$} \\
\hline Pertemuan 2 & 94 & 100 & $94 \%$ & \\
\hline
\end{tabular}

Data di atas tercantum dalam gambar di bawah ini.

Gambar 1.5 Keterampilan Guru dalam Mengajar Siklus II

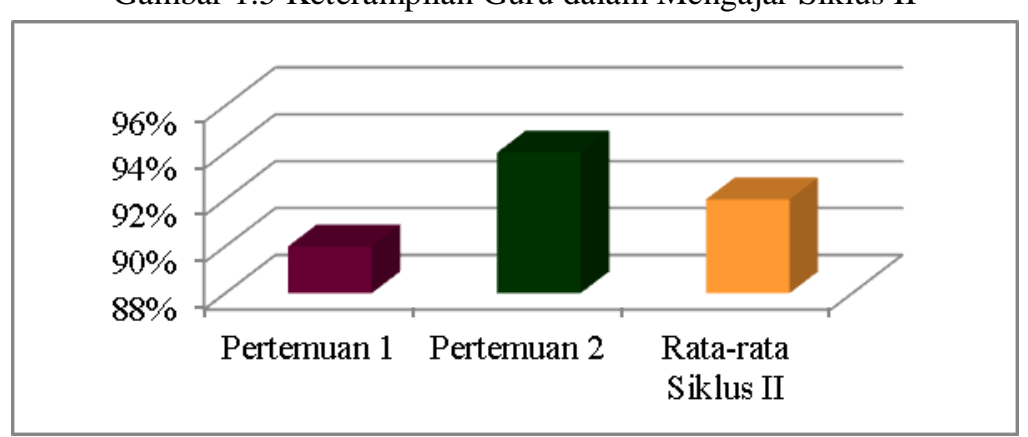

74| Jurnal Kredo

Vol. 2 No. 1 Oktober 2018 


\section{2) Aktivitas Belajar Siswa Siklus II}

Peningkatan aktivitas belajar siswa pada siklus II semakin terlihat. Hal ini dibuktikan dengan keberanian dalam mengutarakan pendapat serta menjawab pertanyaan yang guru ajukan. Kinerja dalam kelompok juga semakin baik, yang pada awalnya masih mementingkan ego dan masih takut bertanya, kini seluruh anggota kelompok tidak segan untuk saling membantu menyelesaikan tugas dari guru, siswa sudah tidak lagi mengalami kebingungan tentang apa saja yang harus dikerjakan tanpa harus mendapatkan penjelasan dari guru yang berulang-ulang. Partisipasi siswa selalu mengalami peningkatan pada setiap pertemuan. Terbukti NNA, AIAB, dan PA dengan sukarela memberikan contoh membaca puisi kepada teman-teman mereka di depan kelas. Keberanian tersebut didorong oleh motivasi dari guru.

Tabel 1.5 Aktivitas Siswa Siklus II

\begin{tabular}{|c|c|c|c|}
\hline Siklus II & Total Skor & Persentase & $\begin{array}{c}\text { Rata-rata } \\
\text { Skor }\end{array}$ \\
\hline Pertemuan 1 & 774 & $80 \%$ & \multirow{2}{*}{$82 \%$} \\
\hline Pertemuan 2 & 823 & $83 \%$ & \\
\hline
\end{tabular}

Hasil observasi aktivitas belajar siswa siklus II dapat diamati pada gambar 1.6 berikut.

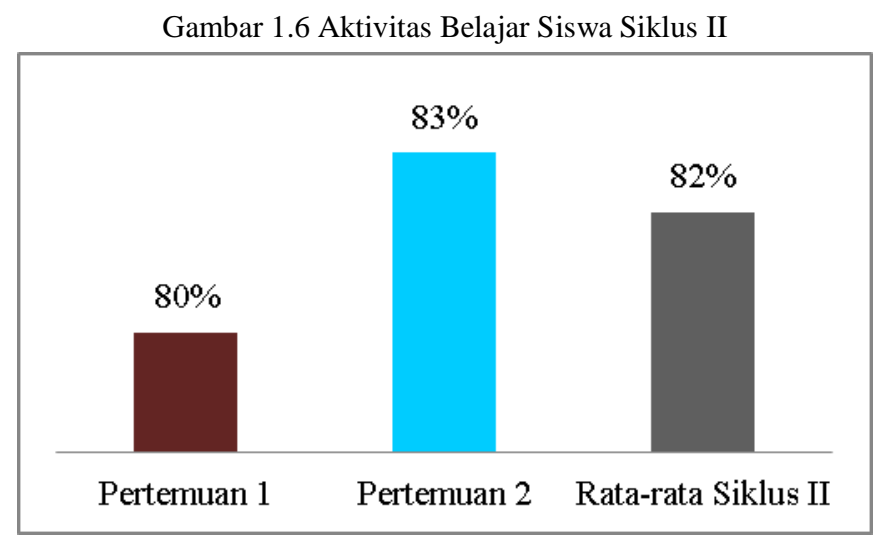

\section{3) Keterampilan Membaca Puisi Siklus II}

Penilaian hasil belajar membaca puisi siswa kelas V SD 1 Tritis Jepara pada siklus II sudah optimal karena kelemahan siklus I mampu guru atasi. Siswa melakukan latihan membaca puisi secara mandiri agar mereka tampil maksimal saat penilaian. Siswa lebih serius dan disiplin dalam pembelajaran, sudah tidak terdapat siswa yang bergurau dengan temannya. Perubahan sikap siswa menuju sikap yang lebih positif tentu saja mempengaruhi nilai hasil belajar membaca puisi, keduanya saling mengalami peningkatan.

Pendekatan guru secara personal pada siswa yang belum lancar membaca puisi dan siswa yang belum tuntas disambut gembira, 
karena ini juga dapat dikatakan sebagai motivasi bagi mereka. Hal ini tak terlepas dari model CIRC yang guru gunakan serta adanya media video pembacaan puisi yang menjadikan mereka semakin antusias karena sangat jarang teknologi yang digunakan ketika pembelajaran di kelas, sehingga nilai dari prasiklus meningkat pada siklus I, dan semakin terlihat peningkatan yang signifikan pada siklus II. Berikut ini merupakan tabel peningkatan keterampilan membaca puisi siswa.

Tabel 1.6 Peningkatan Keterampilan Membaca Puisi Siswa Prasiklus, Siklus I, dan Siklus II

\begin{tabular}{|c|c|c|c|c|}
\hline \multirow{2}{*}{ KKM } & $\begin{array}{c}\text { Kegiatan } \\
\text { Belajar }\end{array}$ & $\begin{array}{c}\text { Ketuntasan } \\
\text { Belajar }\end{array}$ & $\begin{array}{c}\text { Jumlah } \\
\text { Siswa }\end{array}$ & Persentase \\
\hline \multirow{4}{*}{$\geq 75$} & \multirow{2}{*}{ Prasiklus } & Tuntas & 16 & $57 \%$ \\
\cline { 3 - 5 } & \multirow{2}{*}{ Siklus I } & Tidak Tuntas & 12 & $43 \%$ \\
\cline { 3 - 5 } & & Tuntas & 18 & $64 \%$ \\
\cline { 3 - 5 } & \multirow{2}{*}{ Siklus II } & Tidak Tuntas & 10 & $36 \%$ \\
\cline { 3 - 5 } & & Tidak Tuntas & 25 & $89 \%$ \\
\cline { 3 - 5 } & & & & $11 \%$ \\
\hline
\end{tabular}

Berdasarkan Tabel 1.6 tersebut, maka dapat disajikan gambar berikut ini.

Gambar 1.7 Peningkatan Keterampilan Membaca Puisi Siswa Prasiklus, Siklus I, dan Siklus II

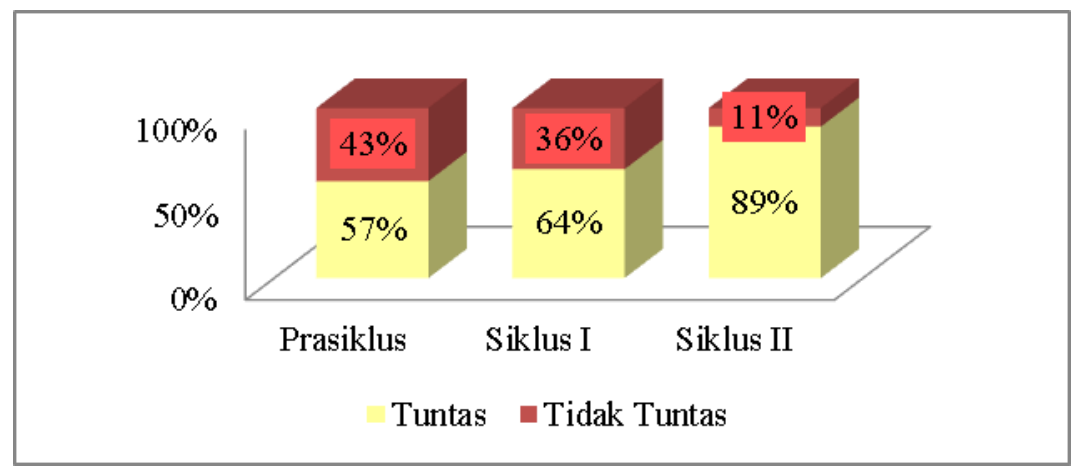

\section{Refleksi Pembelajaran Siklus II}

Berdasarkan hasil analisis pada siklus II, pembelajaran yang dilaksanakan mengalami peningkatan dari siklus sebelumnya. Hal ini dibuktikan pula dengan meningkatnya keterampilan guru dalam mengajar, guru menguasai kondisi kelas, sehingga berpengaruh pada aktivitas siswa. Aktivitas siswa dalam belajar semakin baik dan terlihat juga peningkatannya, dan hasil penilaian keterampilan membaca puisi siswa tergolong dalam kategori tinggi. Jadi dapat disimpulkan bahwa keseluruhan indikator yang guru tentukan berhasil dilaksanakan dengan baik.

\section{b. Pembahasan}

Pengamatan keterampilan membaca puisi dengan model CIRC berbantuan media video pembacaan puisi pada setiap siklusnya selalu mengalami peningkatan. Keterampilan guru dalam mengajar pada siklus I pertemuan pertama memperoleh persentase sebesar $82 \%$ dengan kriteria sangat baik. 10 indikator yang guru tentukan, 9 
indikator memperoleh skor 4 dan satu indikator memperoleh skor 5 . Sedangkan pertemuan kedua persentase meningkat menjadi $86 \%$ dengan kriteria sangat baik, data ini didukung dari 10 indikator, 7 indikator mendapatkan skor 4 dan 3 indikator mendapatkan skor 5 .

Penilaian keterampilan guru dalam mengajar dibantu oleh teman sejawat. Kekurangan pembelajaran pada siklus I antara lain kurang jelas dalam menerangkan tahapan model CIRC yang akan digunakan dalam pembelajaran, siswa masih pasif, kelompok masih kebingungan dalam menjalankan tugas dari guru, serta pengelolaan kelas belum terlalu baik.

Kekurangan di siklus I tersebut direfleksikan guru serta diperbaiki pada siklus II. Siklus II, keterampilan mengajar guru mengalami peningkatan. Pertemuan pertama memperoleh persentase sebesar $90 \%$ dengan kriteria sangat baik. 10 indikator yang diamati, 5 diantaranya memperoleh skor 4 dan sisanya memperoleh skor 5. Pertemuan kedua juga mengalami perningkatan dari pertemuan sebelumnya, persentase yang awalnya sebesar 90\% menjadi $94 \%$, kriteria sangat baik dan hanya 3 indikator yang memperoleh skor 4 , selebihnya skor 5. Peningkatan yang terjadi merupakan dampak dari perbaikan pembelajaran yang guru upayakan. Guru jelas ketika memberikan penjelasan model CIRC sehingga siswa sudah tidak lagi bertanya berulang-ulang, suasana menjadi lebih kondusif hidup karena siswa mulai aktif berpendapat.

Penilaian aktivitas belajar siswa tidak terlepas dari peningkatan pada tiap siklusnya. Siklus I pertemuan I persentase aktivitas siswa sebesar $71 \%$, skor total 700 dengan rata-rata skor 25. Pertemuan II mengalami peningkatan kembali menjadi $77 \%$, skor total 750 dengan rata-rata skor 27. Apabila dirata-rata, persentase aktivitas belajar siswa siklus I pertemuan 1 dan 2 mendapatkan 74\%. Permasalahan-permasalahan yang dihadapi pada siklus I seperti siswa yang masih bersenda gurau dengan temannya, kurang disiplin pada saat mengikuti pembelajaran, serta masih pasif membuat pembelajaran siklus I harus segera diperbaiki pada siklus II.

Berdasarkan tabel dan diagram, siklus II hasil aktivitas belajar siswa mengalami peningkatan. Siklus II pertemuan I persentase yang didapat adalah sebesar $80 \%$, total skor 774 dengan rata-rata skor 28. Sementara itu peningkatan juga kembali terlihat pada siklus II pertemuan 2 dimana persentase yang didapat adalah sebesar $83 \%$, total skor 823 dengan rata-rata skor 29. Apabila dirata-rata, persentase siklus II pertemuan 1 dan 2 mendapatkan 82\%. Berkaca dari kendala pada siklus I, siklus II guru sudah mampu memberikan motivasi dan penguatan pada siswa sehingga mereka berani menjawab bahkan mengajukan pertanyaan, kerjasama kelompok semakin solid, dan keadaan kelas semakin tertib. Hal inilah yang menyebabkan aktivitas siswa selalu meningkat pada setiap pertemuannya.

Data hasil nilai keterampilan membaca puisi siswa prasiklus menunjukkan dari 28 siswa, hanya 16 yang tuntas dengan persentase $57 \%$, sedangkan 12 lainnya dinyatakan tidak tuntas dengan persentase $43 \%$. Rata-rata nilai hasil belajar membaca puisi siswa prasiklus sebesar $66 \%$. Permasalahan yang terjadi dikarenakan siswa jenuh dengan cara pembelajaran yang guru 
lakukan hanya sekadar bercerita atau ceramah tanpa memberikan inovasi pembelajaran seperti penggunaan model dan media, hal ini menyebabkan siswa kurang menaruh perhatian pada mata pelajaran Bahasa Indonesia khususnya materi membaca puisi yang dikenal siswa tidak sama dengan membaca karya sastra lain. Adanya model CIRC berbantuan media video pembacaan puisi diharapkan mampu meningkatkan minat dan keterampilan siswa dalam membaca puisi.

Siklus I, keterampilan membaca puisi siswa mengalami kenaikan dari prasiklus. Jumlah siswa tuntas 18 siswa dengan persentase 64\%, sedangkan 12 siswa tidak tuntas dengan persentase $36 \%$. Rata-rata nilai hasil belajar membaca puisi siswa siklus I sebesar $67 \%$. Peningkatan keterampilan membaca puisi siswa siklus I dikarenakan model CIRC diterapkan, dibantu dengan media video pembacaan puisi yang semakin menambah antusias siswa. Pembelajaran siklus I tergolong sudah baik namun sebagian besar siswa masih kurang maksimal dalam gaya, ekspresi, intonasi, dan lafal ketika membaca puisi. Hal ini perlu diperbaiki agar kualitas pembelajaran siklus II semakin baik lagi.

Keterampilan membaca puisi siswa siklus II kembali meningkat dari siklus I. 25 siswa termasuk dalam kategori tuntas dengan persentase $89 \%$, hanya 3 siswa yang masin belum mencapai ketuntasan dengan persentase $11 \%$. Rata-rata nilai hasil belajar membaca puisi siswa siklus II sebesar 76\%. Nilai KKM yang ditentukan SD 1 Tritis Jepara $\geq 75$. Peningkatan pada siklus
II terjadi karena guru melihat celah kekurangan pada siklus I kemudian diperbaiki. Selain model CIRC dan media video pembacaan puisi, agar siswa semakin mantap dalam gaya, ekspresi, intonasi, dan lafal saat membaca puisi, guru memberikan contoh langsung dan mengajak siswa membaca puisi secara serentak. Selanjutnya siswa saling belajar membaca puisi dalam kelompok lalu berlatih secara mandiri. Inilah yang menyebabkan keterampilan membaca puisi siswa siklus II meningkat.

Berdasarkan analisis nilai keterampilan membaca puisi siswa kelas V SD 1 Tritis Jepara, ditemukan empat gejala, antara lain.

1) Turun-naik

Awalnya siswa dalam gejala ini kurang bersemangat mengikuti pembelajaran namun pada pertemuan berikutnya motivasi mereka meningkat. Siswa dalam gejala ini yaitu AAR, EV, FSL, HAY, LA, MAR, dan DS.

2) Naik-tetap

Motivasi siswa mengikuti kegiatan pembelajaran tinggi, masih mengalami kebingungan tapi mencapai nilai KKM. Siswa dalam gejala ini yaitu AIAB.

3) Tetap-naik

Siswa bersemangat mengikuti pembelajaran. Siswa dalam gejala ini adalah KAS dan LR.

4) Naik-naik

Semangat dan dorongan siswa pada pembelajaran meningkat yang berdampak pula pada meningkatnya hasil belajar mereka. Siswa dalam gejala ini antara lain LK, MRS, NPRN, NNA, NS, PA ,PA ,PA, RS, RK, RPP, SA, SA, SMA, ZAF, DAN ASA. 
Tabel 1.7 Persentase Keterampilan Membaca Puisi Siswa Prasiklus, Siklus I, dan Siklus II

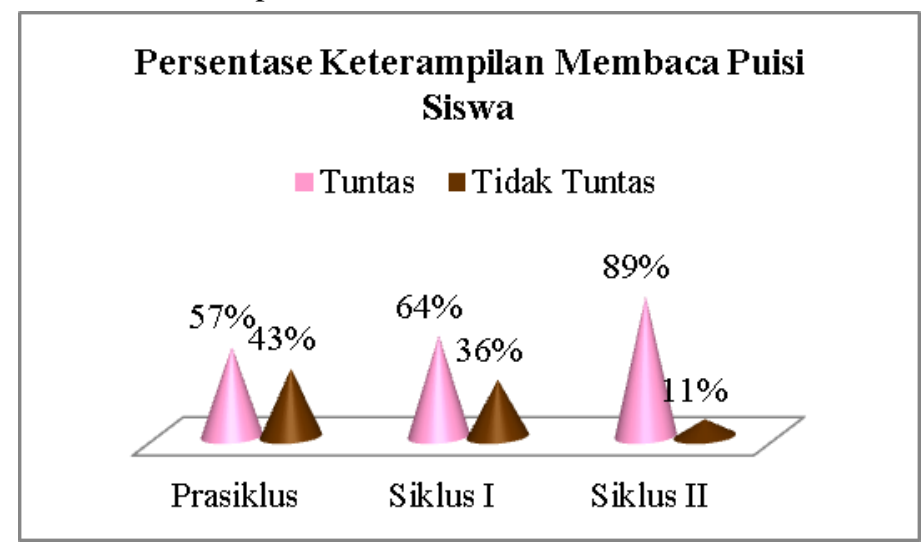

\section{SIMPULAN DAN SARAN}

\section{1) Simpulan}

Simpulan hasil penelitian yang telah dilaksanakan menyatakan bahwa diterapkannya model CIRC dengan media video pembacaan puisi dapat meningkatkan keterampilan membaca puisi siswa kelas V SD 1 Tritis Jepara. Hal ini dibuktikan dengan indikator sebagai berikut.

1) Keterampilan guru dalam mengajar menggunakan model CIRC dibantu media video pembacaan puisi siklus I sebesar $84 \%$ mengalami peningkatan $8 \%$ dalam siklus II menjadi $92 \%$ dengan kategori sangat tinggi.

2) Aktivitas belajar siswa menggunakan model CIRC dibantu media video pembacaan puisi siklus I sebesar $74 \%$ mengalami peningkatan $8 \%$ menjadi $82 \%$ dengan kategori sangat tinggi.

3) Keterampilan membaca puisi siswa menggunakan model CIRC dibantu media video pembacaan puisi belum mencapai KKM pada prasiklus. Hanya 16 siswa yang tuntas dengan persentase $57 \% \%$, sementara 12 siswa belum tuntas dengan persentase $43 \%$ kategori sedang. Siklus I keterampilan membaca puisi siswa telah mencapai KKM dengan persentase $67 \%$ kategori tinggi dan $89 \%$ pada siklus II kategori sangat tinggi.

2) Saran

Saran yang dapat peneliti berikan setelah melaksanakan penelitian antara lain.

1) Siswa hendaknya tertib dan tidak gaduh dalam mengikuti pembelajaran, menghormati dan menghargai guru dengan mendengarkan penjelasan dan patuh pada aturan yang telah disepakati.

2) Bagi Guru

Guru sebagai salah satu komponen penentu keberhasilan pembelajaran sebaiknya mengembangkan kompetensi yang dimiliki secara maksimal. Inovasi dan kreasi pembelajaran juga harus selalu dilakukan agar tercipta siswa yang aktif sehingga membuat pembelajaran menjadi bermakna dan penuh kesan.

3) Bagi Sekolah

Sekolah sebagai tempat menimba ilmu selayaknya juga memfasilitasi kegiatan yang berhubungan dengan pembelajaran secara baik.

4) Bagi Peneliti Lainnya 
Sebelum melakukan penelitian, akan lebih baik jikalau peneliti memastikan dan merencanakan dengan matang kegiatan apa yang nanti akan dilakukan, sehingga hasil yang didapat menjadi optimal, tepat waktu dan tepat guna.

\section{DAFTAR PUSTAKA}

Dalman. 2014. Keterampilan Membaca. Jakarta: PT Rajawali Persada.

Damayanti, D. 2013. Buku Pintar Sastra Indonesia: Puisi, Sajak, Syair, Pantun, dan Majas. Yogyakarta: Araska.

Kariesma, I Km., Zulaikha, S. \& Ganing, N. N. 2014. "Pengaruh Model Pembelajaran CIRC Bermedia Powerpoint terhadap Keterampilan Membaca pada Bahasa Indonesia Kelas IV SD Gugus 1 Kuta Badung." $e$ Journal PGSD, 2 (2), 2.

Klein, M. L, S. Peterson, \& L. Semingston. 1991. Teaching and Reading in Elementary Grades. Boston: Allyyn and Bacon.

Kridalaksana, Harimurti. 2009. Kamus Linguistik. Jakarta: PT Gramedia.

Ngatiyem. 2011. "Meningkatkan Keterampilan Menulis Puisi Bebas dengan Menggunakan Media Video pada Kelas VII MTSN Banjar Selatan 1 Kota Banjarmasin. Jurnal Meretas, 4 (1), 87.

Nurgiyantoro, Burhan. 2005. Sastra Anak. Yogyakarta: Gadjah Mada University Press.

Rahim, Farida. 2008. Pengajaran Membaca di Sekolah Dasar. Jakarta: PT Bumi Aksara.

Salad, Hamdy. 2014. Panduan Wacana dan Apresiasi Seni Baca Puisi. Yogyakarta: Pustaka Pelajar.

Shoimin, Aris. 2014. 68 Model Pembelajaran Inovatif dalam Kurikulum 2013. Yogyakarta: Ar-Ruzz Media.

Tarigan, H. G. 2008. Membaca sebagai suatu Keterampilan Berbahasa. Bandung: Percetakan Angkasa.

Waluyo, H. J. 2010. Pengkajian dan Apresiasi Puisi. Salatiga: Widya Sari Press Salatiga. 